\title{
Characterization of high-milk-protein powders upon rehydration under various salt concentrations
}

\author{
R. Hussain, C. Gaiani, ${ }^{1}$ L. Aberkane, and J. Scher \\ LIBio, Nancy Université, Laboratoire d'Ingénierie des Biomolécules, 54505 Vandoeuvre Les Nancy Cedex, France
}

\begin{abstract}
Rehydration of native micellar casein and native whey isolate protein powders was followed in different ionic environments. Solutions of $\mathrm{NaCl}$ and $\mathrm{CaCl}_{2}$ in the concentration range of 0 to $12 \%$ (wt\%) were used as rehydration media. The rehydration profiles obtained were interpreted in terms of wetting, swelling, and dispersion stages by using a turbidity method. Two behaviors were observed depending on the salt concentration. For native micellar casein powder, a significant change was observed between 3 and $6 \% \mathrm{NaCl}$ and between 0.75 and $1.5 \% \mathrm{CaCl}_{2}$. The first behavior (low salt concentration) presents a typical rehydration profile: quick wetting, swelling, and long dispersion stage. The dispersion stage of the second behavior (high salt concentration) was significantly shortened, indicating a strong modification of the protein backbone. The rehydration of whey protein powder was less influenced by salts. At low salt concentrations, a typical profile for whey powders was observed: wetting with lump formation and no swelling followed by a quick dispersion. At high $\mathrm{CaCl}_{2}$ concentrations, no turbidity stabilization was observed, indicating a possible protein unfolding and denaturation. Additionally, the changes in secondary structures of the 2 proteins upon salt increase were followed by Fourier transform infrared spectroscopy and confirmed the different profiles observed.
\end{abstract}

Key words: ionic environment, milk protein, powder rehydration

\section{INTRODUCTION}

Milk proteins are a valuable source of protein because they combine a high nutritional value and various functional properties (e.g., gelling, emulsifying). Based on the results of Walstra et al. (1999), whole milk powders mainly consist of lactose (approximately 38\%), whey proteins (approximately 4\%), caseins (approximately

Received April 7, 2010.

Accepted September 14, 2010.

${ }^{1}$ Corresponding author: Claire.Gaiani@ensaia.inpl-nancy.fr
$20 \%$ ), and milk fat (approximately 26\%). Caseins are the most important class of milk proteins and are the network formers in dairy products such as yogurt and cheese. In milk, caseins exist as micelles, comprising 4 types: $\alpha_{S 1}, \alpha_{S 2}, \beta$, and $\kappa$-casein (Swaisgood, 1996). Whey proteins are defined as the group of milk proteins that remain soluble in milk serum or whey after precipitation of casein at $\mathrm{pH} 4.6$ and $20^{\circ} \mathrm{C}$. This group includes principally $\beta$-lactoglobulin and $\alpha$-lactalbumin, but also includes minor proteins fractions (Farrell et al., 2004). There is a continuing need to develop innovative, dairy-based ingredients; native micellar casein (NMC) and native whey isolate proteins (NWI) are 2 such ingredients and have been made possible by developments in the membrane microfiltration processing of skim milk (Fauquant et al., 1988).

Milk proteins can be spray dried easily and the resulting protein powders present with high total protein contents (90\% of total solids). The NMC powder is a useful ingredient for the food industry because of its high protein content and its ability to be used as a relevant model for milk micelles (Maubois, 2002). In addition, this powder presents excellent rennet-coagulating properties and enhances the capacity for cheese making (Pierre et al., 1992). Despite these properties, native micellar casein powders present very slow dispersion properties, making the total rehydration process time consuming. Native whey isolate proteins present specific applications in many foodstuffs (Jayaprakasha and Brueckner, 1999) because of various functional properties, such as solubility, viscosity, water binding, whipping, and emulsification. Compared with NMC, NWI powders present opposite rehydration properties (Gaiani et al., 2007). The wetting stage was found to be very slow, whereas the dispersion stage was quick; the total rehydration was fastest for NWI powders.

Milk protein powders are frequently dried to stabilize and transport. This is the reason why rehydration ability is an essential quality attribute of the powder. Consequently, rehydration is often realized by the industry before use (King, 1966). Freudig et al. (1999) confined powder rehydration to 4 stages. The first, called the "wettability" stage, involves the ability of powder to absorb water. The "sinkability" stage is the ability of 
the powder to sink into the water. The third stage is "dispersibility," which is the ability to disperse in single particles throughout the water. The final stage, also called dissolution, relates to the separation between molecules during the rehydration process. The addition of salts was found to have a major influence on the hydration process of casein by modifying its structure and mineral composition (Famelart et al., 1999; Gaucheron et al., 2000). The physical and functional attributes of whey proteins with the addition of mono- $(\mathrm{NaCl})$ and divalent $\left(\mathrm{CaCl}_{2}\right)$ salts also have been well documented by Kuhn and Foegeding (1991). For whey proteins, salt addition may enhance aggregation and affect the hydration process by electrostatic-shielding, ion-specific hydrophobic interactions and cross-linking of adjacent anionic molecules by forming protein-Ca-protein bridges (Kinsella et al., 1989; Ju and Kilara, 1998).

The aim of this work was to investigate the influence of the ionic environment (distilled water, $\mathrm{NaCl}$ solution, and $\mathrm{CaCl}_{2}$ solution) on milk proteins powder rehydration and secondary structure. From an industrial point of view, our project is significant because of the dearth of basic data on the dynamics of hydration in connection with environmental conditions, and because of the poorly controlled rehydration process in the food industry.

\section{MATERIALS AND METHODS}

\section{Samples}

The NMC powder was obtained from International Dairy Ingredient (Arras, France). This industrial powder (Promilk 872B) is obtained by microfiltration from milk and has a high percentage of native micellar casein (casein: $83.5 \%$, whey: $3.4 \%$, fat: $0.3 \%$, lactose: $0.4 \%$, ashes: $7.6 \%$, and moisture: $4.8 \%$ ). The NWI powder (Prolacta 90) was provided by Lactalis (Laval, France) and was obtained by membrane-tangential ultrafiltration and diafiltration of microfiltrate collected during NMC production (casein: $3.5 \%$, whey: $86.4 \%$, fat: $0.5 \%$, lactose: $1.0 \%$, ashes: $3.1 \%$, and moisture: $5.5 \%$ ). The $\mathrm{NaCl}$ and $\mathrm{CaCl}_{2}$ salts were furnished by VWR (Prolabo, Haasrode, Belgium) and Merck KGaA (Darmstadt, Germany) respectively.

\section{Rehydration Media}

Rehydration of NMC and NWI powders was studied at $24^{\circ} \mathrm{C}$ in 2 different media ( $\mathrm{NaCl}$ and $\mathrm{CaCl}_{2}$ solutions) at different concentrations $(0,0.75,1.5,2.25,3,6,9$, and $12 \% \mathrm{wt} / \mathrm{vol}$ ). Sodium azide (Merck KGaA) was added as an antimicrobial agent in each rehydration medium $(0.2 \mathrm{~g} / \mathrm{L})$.

\section{Rehydration Setup}

The experimental setup used to follow the rehydration kinetics has been detailed by Gaiani et al. (2005). The rehydration was carried out in a 2 -L vessel equipped with a 4-blade, $45^{\circ}$ impeller (R 100 impeller: $8 \mathrm{~cm}$ diameter) rotating at $450 \mathrm{rpm}$ (Lightnin LabMaster mixer, Axflow, France). The turbidity sensor was positioned through the vessel wall to avoid disturbances during stirring. A turbidity meter (Analite NEP 160, McVan Instruments, Mulgrave, VIC, Australia) was used to monitor turbidity changes accompanying powder rehydration. A measurement system for continuous monitoring (Almemo 8990-8 V5, Holzkirchen, Germany) was connected to the turbidity meter. Turbidity data were collected automatically every $5 \mathrm{~s}$ for $25,000 \mathrm{~s}$ at least in triplicate. For all experiments, the powder concentration was fixed at $5 \%(\mathrm{wt} / \mathrm{vol})$. The powder was poured in less than $5 \mathrm{~s}, 60 \mathrm{~s}$ after starting the monitoring to obtain a correct stabilization of turbidity.

\section{Infrared Measurements}

The Fourier transform infrared (FTIR) scans were obtained with a Tensor 27 mid-FTIR spectrometer (Bruker, Karlsruhe, Germany) equipped with a total attenuated reflection mode cell and a mercury-cadmium-telluride detector cooled with liquid $\mathrm{N}_{2}$. Scanning rate was $20 \mathrm{kHz}$, and 256 scans were used for reference and samples between 4,000 and $850 \mathrm{~cm}^{-1}$. The nominal instrument resolution was $2 \mathrm{~cm}^{-1}$. Spectra of references were recorded on water, $\mathrm{NaCl}$, or $\mathrm{CaCl}_{2}$ salt solutions according to their concentrations. The protein solution $(2 \mathrm{~mL})$ was put on the ZnSe crystal of the optical cell and left for $5 \mathrm{~min}$, allowing for protein adsorption onto the crystal. This ameliorated the signal:noise ratio of FTIR spectra considerably. Analyses were performed on totally rehydrated powders in salt media $(\mathrm{NaCl}$ and $\left.\mathrm{CaCl}_{2}\right)$ at different concentrations $(0,0.75,1.5,2.25,3$, $6,9,12 \%)$. To obtain a total rehydration of the powder, the powder was left under stirring 1 night at $24^{\circ} \mathrm{C}$ in each medium. The total rehydration was confirmed by dynamic light scattering (data not shown). All treatments were carried out with OPUS software (Bruker, Karlsruhe, Germany). Raw absorbance spectra were smoothed using a 9-points Savitsky-Golay smoothing function and cut between 1,720 and $1,200 \mathrm{~cm}^{-1}$ corresponding to amide regions (I, II, and III). Elastic baseline correction using 200 points was then applied to spectra. After that, spectra were centered and normalized using OPUS software.

\section{Statistical Analyses}

Statistical analysis was carried out by using the software KyPlot version 2.0. For comparisons between 
powder rehydration in water and other rehydrations (i.e., $\mathrm{NaCl}, \mathrm{CaCl}_{2}$ ), parametric multiple tests were performed (Dunnett test with NMC and NWI powder rehydration in water as control). The significance levels were ${ }^{* * *} P<0.001,{ }^{* *} P<0.01,{ }^{*} P<0.05$, and NS, $P$ $>0.05$.

\section{RESULTS}

\section{Micellar Casein Rehydration in Different lonic Environments}

Micellar Casein Rehydration in Water. The rehydration of $5 \%$ native micellar casein in water was followed with a turbidity sensor. The mean profile obtained in water is presented in Figure 1A. The turbidity profile was interpreted in terms of wetting, swelling, dispersion, and total rehydration stages as already described in detail by Gaiani et al. (2007). The rehydration profiles show an early wetting stage with a first turbidity peak obtained $10 \mathrm{~s}$ after powder addition. The wetting stage was followed by a light turbidity decrease corresponding with the swelling stage $2 \mathrm{~min}$ after powder addition. Then, a turbidity increase was observed (i.e., particle dispersion) and was followed by a stabilization of the turbidity $467 \mathrm{~min}$ after powder addition. This stabilization was related to the total rehydration stage.

Micellar Casein Rehydration in $\mathrm{NaCl}$ Solutions. Two rehydration behaviors were obtained for micellar casein rehydration in $\mathrm{NaCl}$ and rehydration times are summarized in Table 1. The first behavior was found for casein rehydration in water with up to $3 \%$ salt $(0,0.75,1.5,2.25$, and $3 \%)$. For these 5 profiles, it is possible to distinguish the following stages: wetting, swelling, and dispersion (behavior I in Figure $2)$. In comparison with water, the rehydration profiles obtained for $0.75,1.5,2.25$, and $3 \% \mathrm{NaCl}$ had longer wetting $(33,37,40$, and $45 \mathrm{~s})$ and swelling (14, 21, 53 and $55 \mathrm{~min}$ ) stages. In comparison with water, the total rehydration was significantly delayed and was not completed, even after $500 \mathrm{~min}$ (no turbidity stabilization). The second behavior (behavior II in Figure 2) was obtained for higher salt concentrations $(6,9$, and $12 \%)$. The wetting stage was still longer than in water $(55,56$, and $62 \mathrm{~s})$, but the total rehydration was significantly shortened (around $230 \mathrm{~min}$ ). For this behavior, the swelling stage was not observed.

Micellar Casein Rehydration in $\mathrm{CaCl}_{2}$ Solutions. Two rehydration behaviors also were established for micellar casein rehydration in $\mathrm{CaCl}_{2}$ (Table 1). The first behavior was noticed only in water and $0.75 \%$ salt (behavior I in Figure 2). For $0.75 \%$ salt, a longer wetting stage in comparison with water was observed (around $45 \mathrm{~s}$ ). The swelling stage also was longer and the total rehydration was not complete, even after 500 min. The second behavior was observed when the salt concentration was augmented (from $1.5 \%$ up to $12 \%$ ). In these cases, the swelling stage was not observed and the total rehydration was significantly shortened (around $200 \mathrm{~min}$ ).

\section{Native Whey Protein Rehydration in Different lonic Environments}

Native Whey Protein Rehydration in Water. The turbidity profile obtained during the rehydration of native whey protein powder in water is presented in Figure 1B. From this mean profile, the first turbidity peak was obtained $23 \mathrm{~s}$ after powder addition. No more swelling stages were observed. The total rehydration was observed after 25 min and was related to turbidity stabilization.

Native Whey Protein Rehydration in $\mathrm{NaCl}$ Solutions. Almost similar rehydration behaviors (behavior I) were observed for NWI rehydration in $\mathrm{NaCl}$ salts solutions up to $12 \%$ salts (Figure 3). For $\mathrm{NaCl}$ concentration up to $6 \%$, no significant difference was observed in the rehydration times (wetting, swelling and total rehydration in Table 1). For 9 and $12 \% \mathrm{NaCl}$, the wetting and total rehydration times were significantly longer.

Native Whey Protein Rehydration in $\mathrm{CaCl}_{2}$ Solutions. Figure 3 represents the 2 rehydration behaviors obtained in $\mathrm{CaCl}_{2}$ salt solutions during NWI rehydration. The first behavior was observed for NWI rehydrated in water with up to $1.5 \%$ salt. For these 3 concentrations, no significant differences were observed between the rehydration times. The turbidity profile (behavior I in Figure 3) showed an early wetting and a short rehydration time. The swelling time was not observed. On the contrary, for the second rehydration behavior (behavior II in Figure 3), the turbidity stabilization was not obtained, even after 100 min. For this behavior, after a period of stabilization, the turbidity increased slowly and regularly. The wetting stage was slightly increased from $23 \mathrm{~s}$ in water to $44 \mathrm{~s}$ in $12 \%$ $\mathrm{CaCl}_{2}$.

\section{Secondary Structure of Milk Proteins in Different lonic Environments}

Native Micellar Casein. Figure 4A shows the original FTIR spectrum (from 1,200 to $1,700 \mathrm{~cm}^{-1}$ ) of native micellar casein totally rehydrated (overnight) in water and in $12 \%$ salt. The amide I peak is easily identifiable and centers on $1,641 \mathrm{~cm}^{-1}$. The amide I region $\left(1,700-1,600 \mathrm{~cm}^{-1}\right)$ is principally associated with the stretching vibrations of peptide carbonyl groups. The 

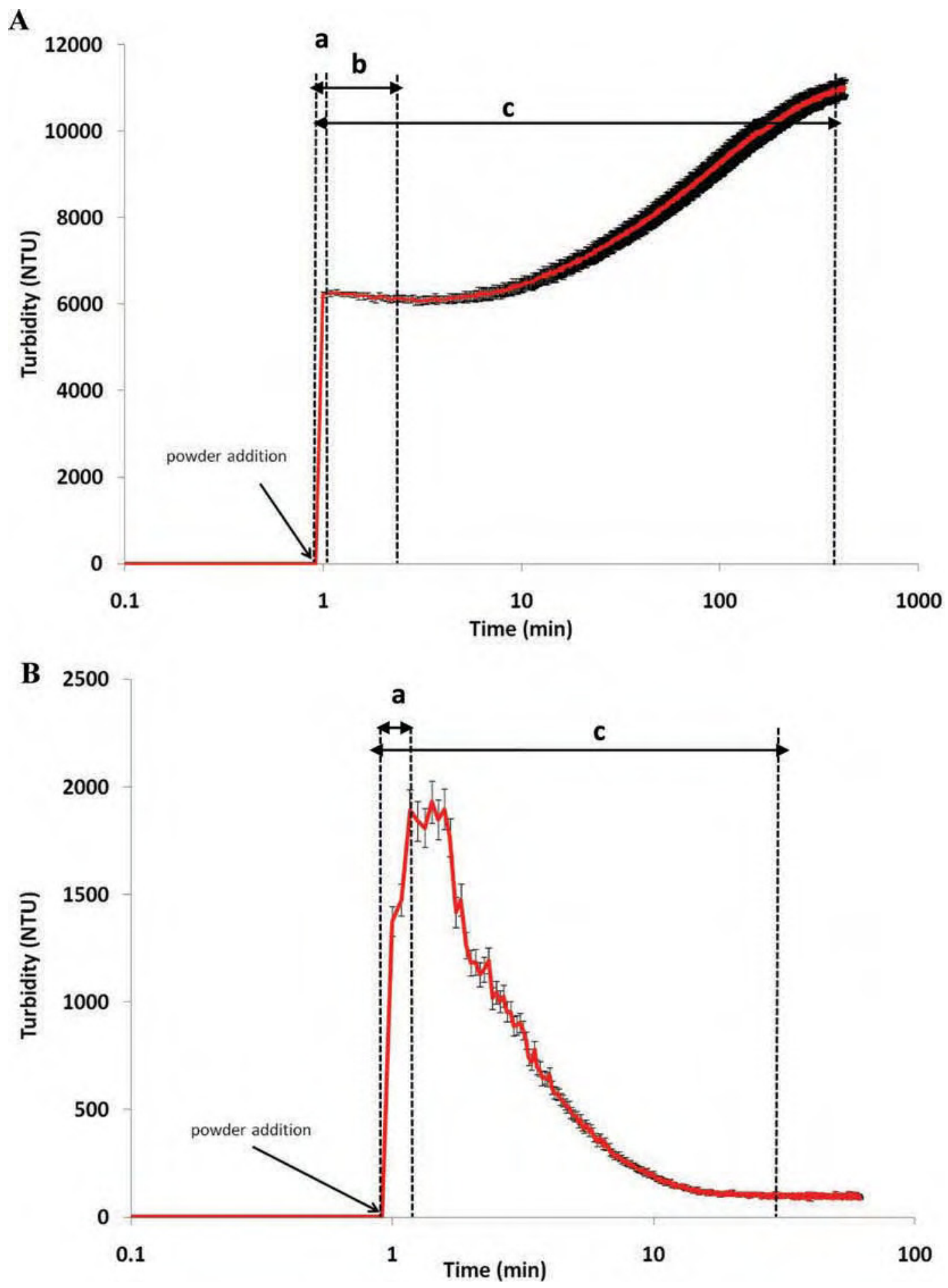

Figure 1. Turbidity profiles (NTU, nephelometric turbidity units) obtained during rehydration of (A) $5 \%$ native micellar casein powder and (B) $5 \%$ whey protein isolate powder at $24^{\circ} \mathrm{C}$ in water. The red (gray) profile is the mean of 3 independent analyses (standard deviation in black): (a) wetting time, (b) swelling time, and (c) total rehydration time. Color version available in the online PDF.

amide II peak, centered on $1,550 \mathrm{~cm}^{-1}(1,600-1,700$ $\left.\mathrm{cm}^{-1}\right)$, is mainly $\mathrm{N}-\mathrm{H}$ bending and $\mathrm{C}-\mathrm{N}$ stretching modes. The amide III region $\left(1,350-1,200 \mathrm{~cm}^{-1}\right)$ presents relatively weak signals, but may be easily resolved and is better defined than amide I and II regions. No differences were observed in the amide II shape for casein rehydrated in water and in a high-ionic environment. On the contrary, amide I and amide III regions 
Table 1. Comparison of the rehydration times obtained for casein and whey proteins powders in the different media compared with native micellar casein (NMC) and native whey isolate (NWI) rehydrated in water ${ }^{1}$

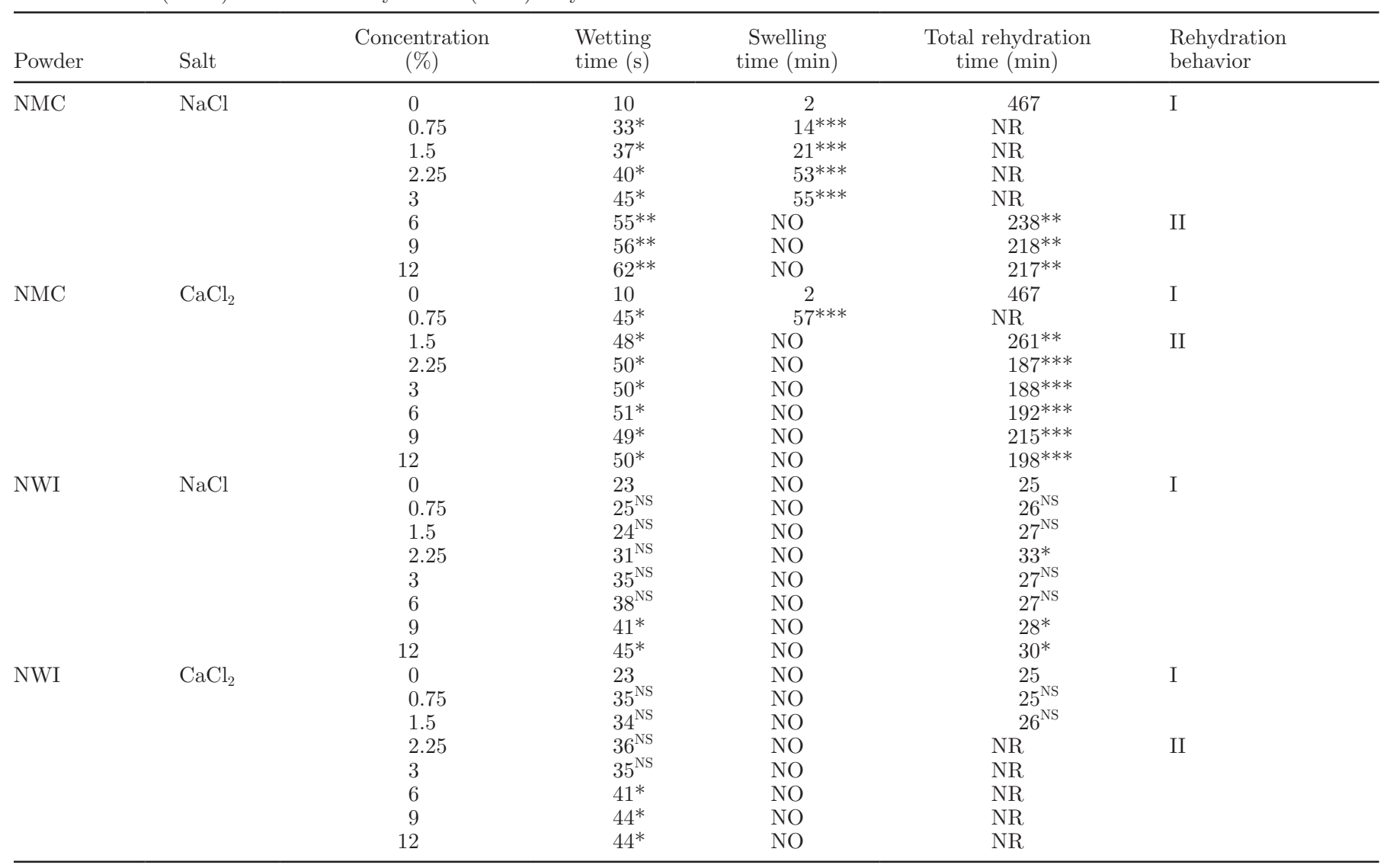

${ }^{1} \mathrm{NR}=$ not rehydrated after 500 and $100 \mathrm{~min}$ for casein and whey, respectively; NO = not observed.

${ }^{* * *} P<0.001,{ }^{* *} P<0.01,{ }^{*} P<0.05$, and ${ }^{\mathrm{NS}} P>0.05$.

presented different shapes in water and in $12 \%$ salt. Intermediate curves were obtained for other concentrations $(0.75,1.5,2.25,3,6$, and $9 \%)$, but were not presented for figure simplification. For casein rehydrated in $\mathrm{NaCl}$ solutions (Figure 4A), the amide I center was significantly shifted from 1,641 to $1,635 \mathrm{~cm}^{-1}$, and the amide III principal peak also was shifted from lower wave numbers $\left(1,249\right.$ to $\left.1,247 \mathrm{~cm}^{-1}\right)$. Casein rehydrated in $\mathrm{CaCl}_{2}$ presented similar shifts. For all rehydration media (each concentration and each salt), the only differences observed were that peak shifts were more important when the salt concentration increase.

Native Whey Proteins Isolate. Figure 4B shows the original FTIR spectrum of whey protein isolate powders totally rehydrated in water and in $12 \%$ salt. The amide I peak centered on $1,630 \mathrm{~cm}^{-1}$, regardless of the salt media. The amide II peak centered on $1,548 \mathrm{~cm}^{-1}\left(1,600-1,700 \mathrm{~cm}^{1}\right)$ and the amide III region $\left(1,350-1,200 \mathrm{~cm}^{-1}\right)$ are only ones influenced by the salt concentration. The amide I region presented different shapes and intensities in water and in $12 \%$ salt. For
NWI rehydrated in $\mathrm{NaCl}$ solutions, the amide I center was only slightly shifted toward lower wave numbers $\left(1,630\right.$ to $\left.1,628 \mathrm{~cm}^{-1}\right)$. The NWI rehydrated in $\mathrm{CaCl}_{2}$ had the same shifts. On average, these shifts amounted to about $2 \mathrm{~cm}^{-1}$ maximum. In conclusion, for all rehydration media (each concentration and each salt), the only significant differences observed were that amide I peaks shifted to lower wave numbers and amide I peak intensity was less important when the salt concentration increased.

\section{DISCUSSION}

\section{Rehydration of Micellar Casein}

In agreement with Gaiani et al. (2005, 2007), the total rehydration of micellar casein in water was timeconsuming, with a quick wetting stage and a very long dispersion stage. The rehydration time obtained in this study (467 min) was in accord with that reported by Gaiani et al. (2007). They found a total rehydration 


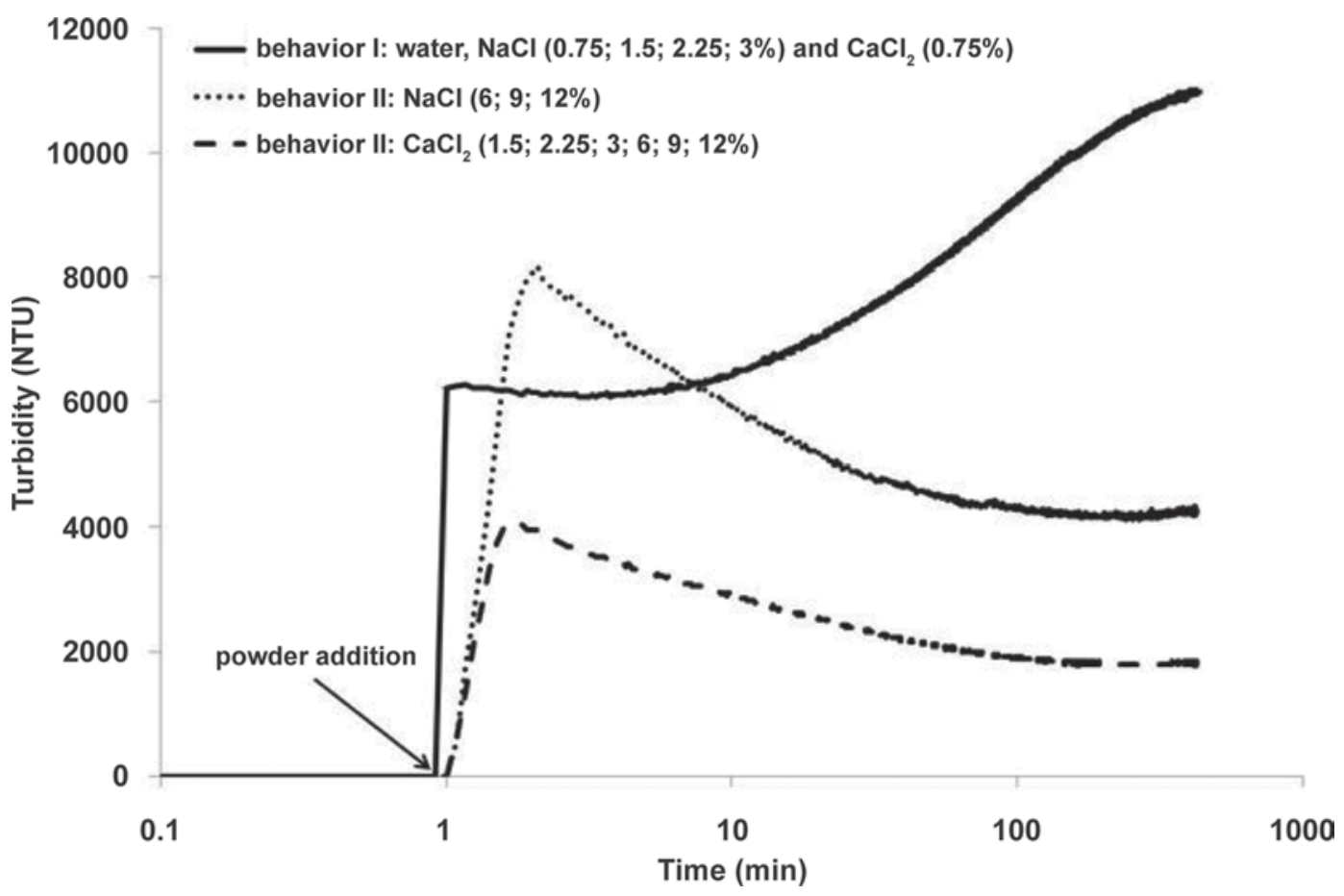

Figure 2. Turbidity profiles (NTU, nephelometric turbidity units) obtained during rehydration of $5 \%$ native micellar casein powder at $24^{\circ} \mathrm{C}$ for 1,000 min in different ionic environments (mean of 3 independent analyses). Behavior I: wetting stage, swelling stage, and long total rehydration stage. Behavior II: wetting stage, no swelling stage, and short total rehydration stage.

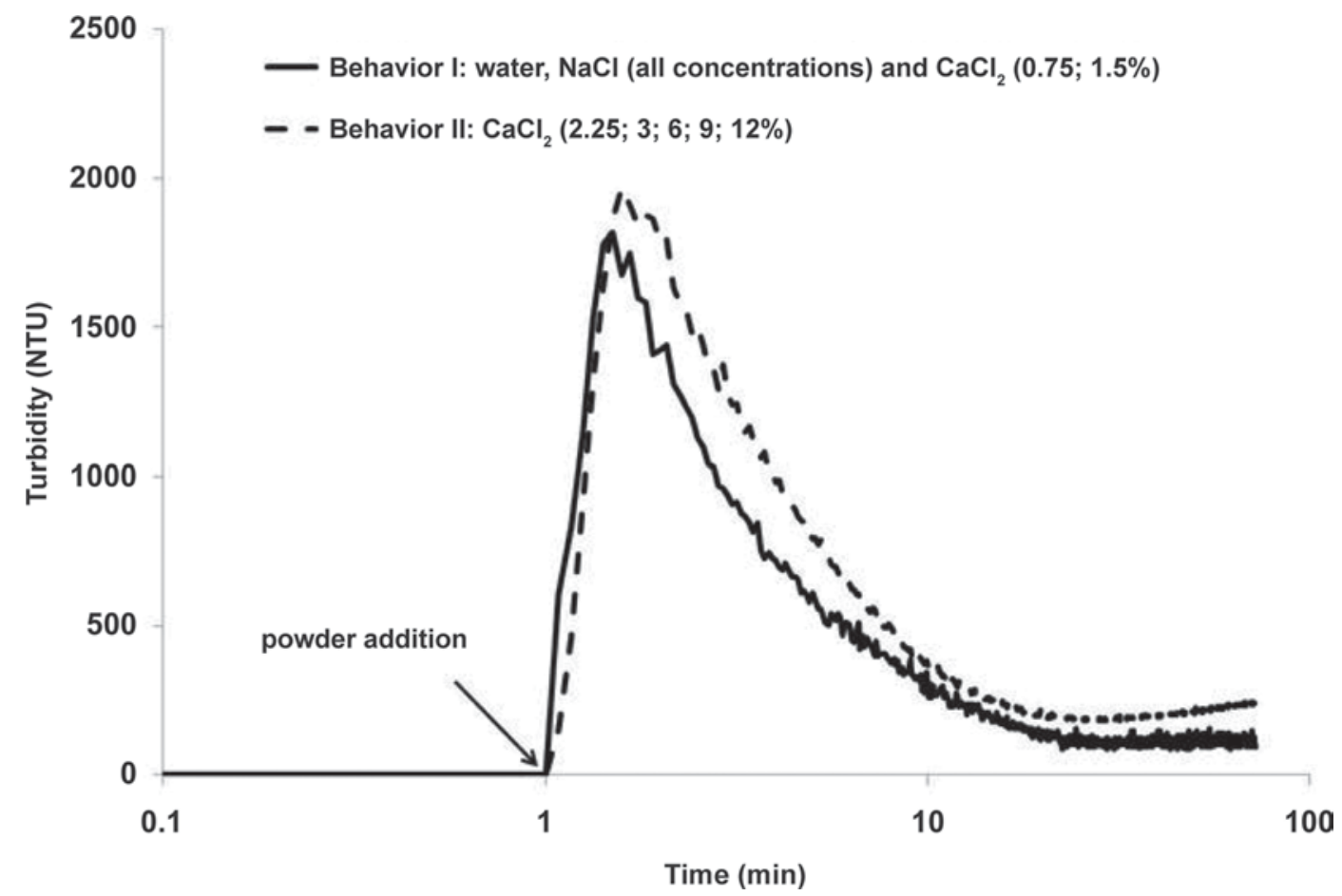

Figure 3. Turbidity profiles (NTU, nephelometric turbidity units) obtained during rehydration of $5 \%$ native whey protein isolate powder at $24^{\circ} \mathrm{C}$ for $1,000 \mathrm{~min}$ in different ionic environments (mean of 3 independent analyses). Behavior I: wetting stage, no swelling stage, and quick total rehydration stage. Behavior II: wetting stage, no swelling stage, and rehydration stage not observed. 


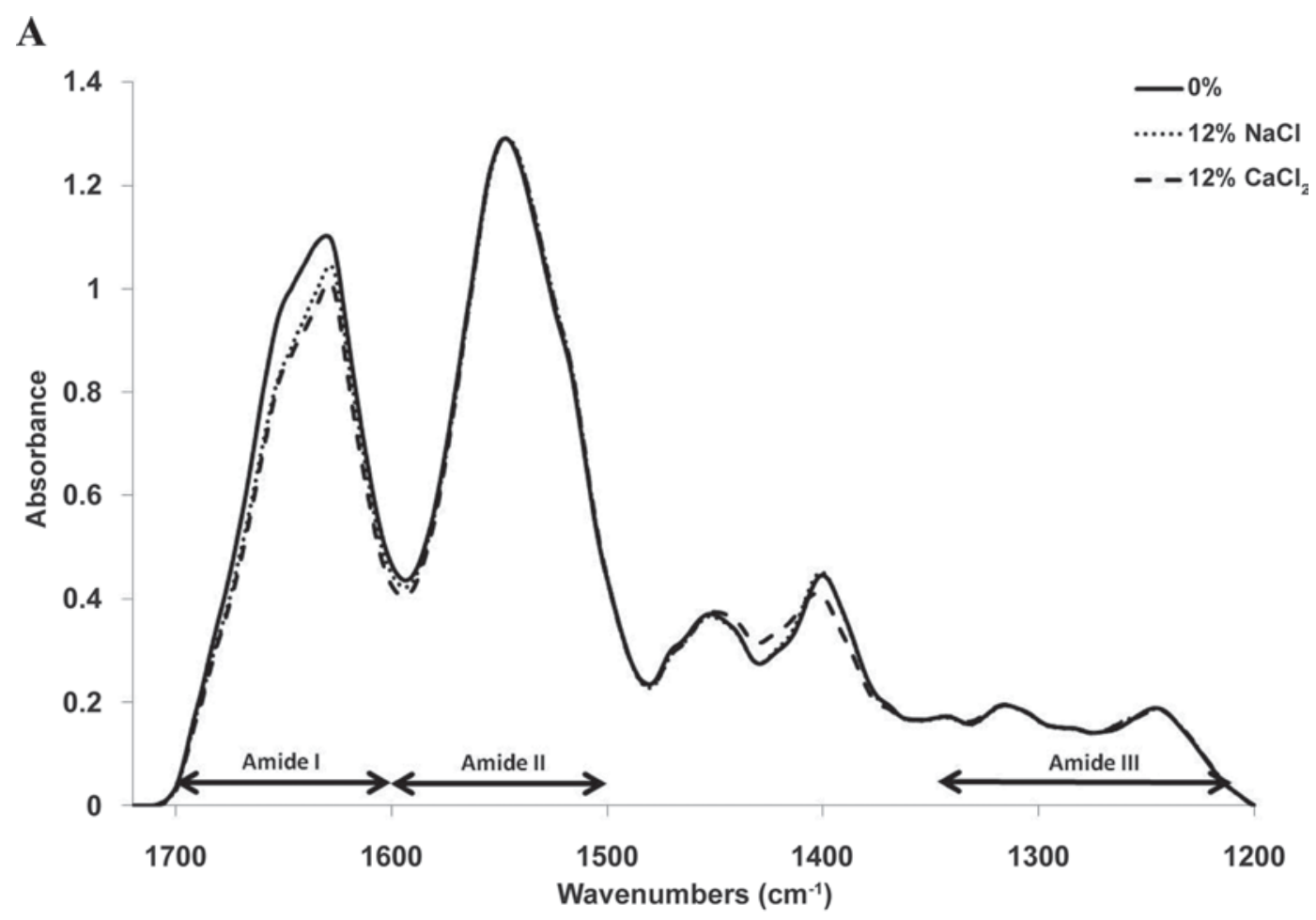

B

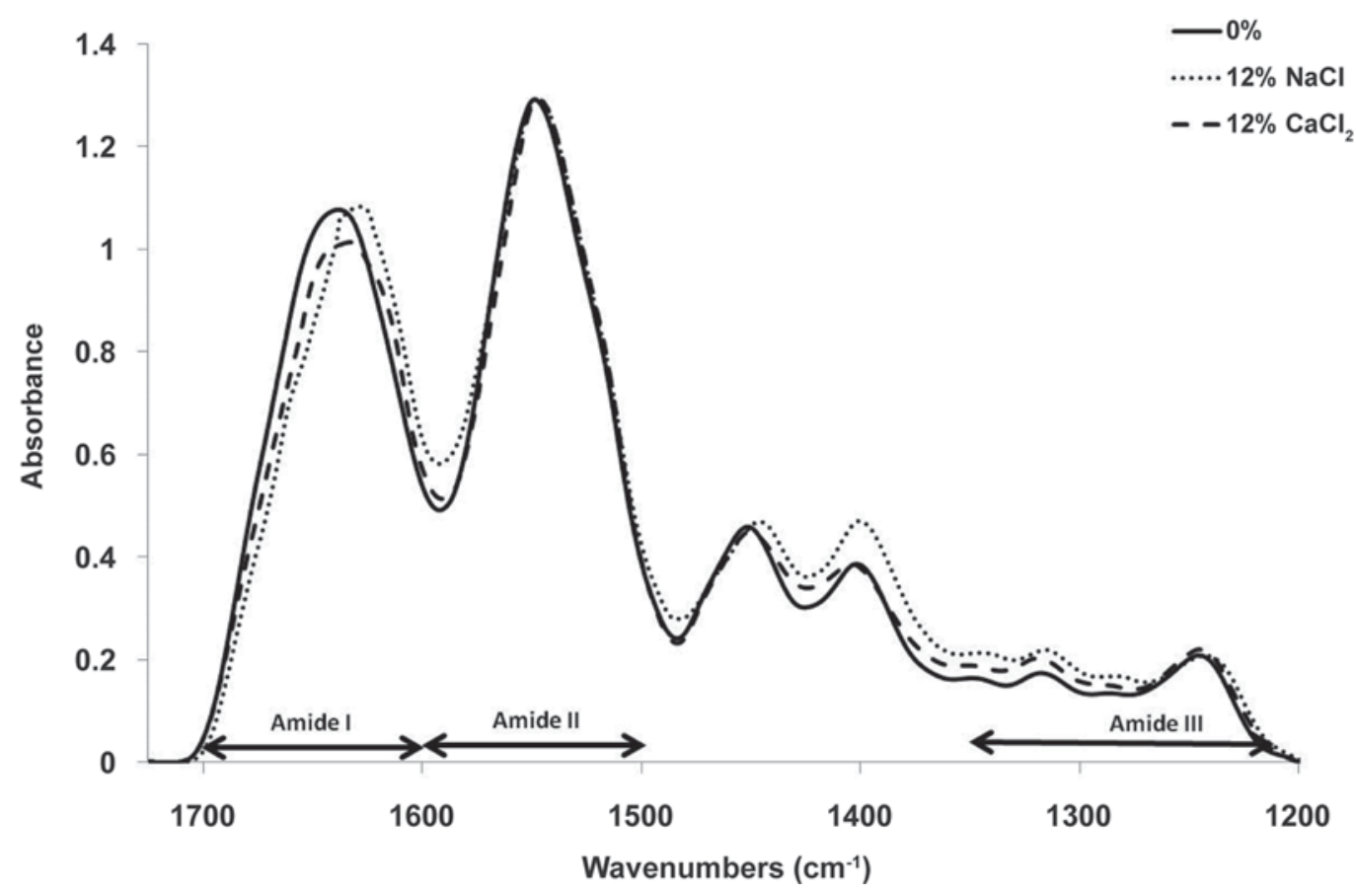

Figure 4. Original Fourier transform infrared spectrum of (A) native micellar casein and (B) native whey protein isolate rehydrated in NaCl and in $\mathrm{CaCl}_{2}$ solutions.

time of $566 \mathrm{~min}$ for nonagglomerated micellar casein powders. Milk protein concentrate powders also are characterized by a low solubility index. Mimouni et al. (2009) reported that a low solubility index for milk protein concentrate powders at room temperature was the result of slow dissolution kinetics rather than the existence of a large amount of insoluble material in the rehydrated powder. In other words, a significant fraction 
of powder material remains undissolved after a reasonable time of reconstitution at room temperature (Havea, 2006). According to these authors, 2 overlapping steps are involved in the rehydration process: the disruption of agglomerated particles into primary particles and, concurrently, the release of material from the powder particles into neighboring aqueous phase. The nature of the insoluble material also has been characterized. It mainly consists of casein micelles linked together by fibril-like protein structures (although their nature has not been clearly established). These linkages seem to involve hydrophobic interactions and nonmicellar caseins dissociated from the micelles during milk protein concentrate powders manufacture (Anema et al., 2006; Havea, 2006). Consequently, micellar casein powders are generally considered to be poorly soluble powders for which rehydration of micelles is a time-consuming process (Jost, 1993).

In $\mathrm{NaCl}$ and $\mathrm{CaCl}_{2}, 2$ rehydration behaviors were observed. The first was similar to the profile obtained in water, but with a time delay: the presence of the wetting stage, swelling stage, and total rehydration. According to previous studies, dispersion of micelles into $\mathrm{NaCl}$ not only increases micellar hydration (Grufferty and Fox, 1985), but also leads to solubilization of calcium and phosphate (Famelart et al., 1999). Moreover, it is well known that increases in ionic strength cause decreases in activity coefficients of the diffusible ions and consequently increases in the dissociation of ion pairs so that hydration of casein micelles is increased because of these changes. Even if salts are hygroscopic and may increase the micelle hydration, no amelioration of the rehydration stages in comparison with water was observed in this study.

The second rehydration behavior was observed from 6 and $1.5 \%$ for $\mathrm{NaCl}$ and $\mathrm{CaCl}_{2}$, respectively. This behavior was different from that seen with water. The total rehydration was significantly shortened and the swelling stage was absent. As has already been observed for powders with quick rehydration times (Gaiani et al., 2007), the swelling stage may be mixed up with the dispersion stage. Our study confirms the findings of Huppertz and Fox (2006). They reported that addition of $\mathrm{NaCl}$ induces changes in physicochemical stability of casein micelles by decreasing negative charge on the micelles. In agreement with Schuck et al. (2002), the addition of $\mathrm{NaCl}$ (at $420 \mathrm{mM}$ ) improved the reconstitution time. These authors observed an infinite reconstitution period for $\mathrm{CaCl}_{2}$ addition at $222 \mathrm{mM}$. Philippe et al. (2005) revealed that the addition of divalent cations $\left(\mathrm{CaCl}_{2}\right)$ into a milk system may cause a strong modification of casein micelles and may decrease micelle hydration. According to Famelart et al. (1999), casein solubilization and hydration showed slight biphasic changes with $\mathrm{CaCl}_{2}$ addition. Negative casein charges are reduced by calcium binding between 0 to $100 \mathrm{mM}$ $\mathrm{CaCl}_{2}$. In conclusion, this second behavior may be the result of a change in micellar structure due to the highsalt environment. This change may occur between 3 and $6 \%(517$ and $1,034 \mathrm{mM})$ in $\mathrm{NaCl}$ and between 0.75 and $1.5 \%$ (67 and $135 \mathrm{mM}$ ) in $\mathrm{CaCl}_{2}$ solutions.

This change in micellar structure was also observed by FTIR (Figures 4). Conformational changes of the casein backbone may be induced by $\mathrm{Ca}^{2+}$ binding to the side chain (Curley et al., 1998). The $\mathrm{Ca}^{2+}$ binding involved serine phosphate and carboxyl groups of glutamate and aspartate residues corresponding to the side chain vibration $\left(1,600-1,610 \mathrm{~cm}^{-1}\right)$. Hence, the shift observed toward lower wave numbers corresponding to the side chain vibration may be due to ion binding. Similar FTIR spectra were observed for casein rehydrated in $\mathrm{NaCl}$.

\section{Rehydration of Whey Proteins}

The NWI powder demonstrated rapid dispersion properties after wetting but was found to have poor wettability, in agreement with Gaiani et al. (2005, 2007). The turbidity instability observed at the beginning of the profile could be due to lump formation flowing past the sensor as already noticed by Freudig et al. (1999). Kinsella (1984) has established that globular proteins bind less water than intact casein micelles. This may explain why the swelling stage was not present or noticeable for whey proteins. An electrophoresis study carried out by Anema et al. (2006) indicated that caseins were the insoluble proteins, whereas the whey proteins showed early and strong soluble behavior.

The first rehydration behavior was observed for NWI rehydration in water, for all $\mathrm{NaCl}$ solutions and up to $1.5 \%$ for $\mathrm{CaCl}_{2}$. All of these profiles showed poor wettability, no swelling, and rapid dispersion. An increase in $\mathrm{NaCl}$ from 0 to $12 \%$ showed no significant effect on the turbidity profile. Globular proteins are shaped in a compact form at a low ionic strength due to selective binding of anions by protein cations. However, at higher ionic strength, 2 factors (i.e., screening of electric charge by electrolyte and association between protein molecules) may result in the formation of a precipitate and may lead to an early hydration (Kinsella, 1982). The second important and observable aspect was that both cationic salts $\left(\mathrm{NaCl}\right.$ and $\left.\mathrm{CaCl}_{2}\right)$ at low concentration show similar behavior and nonsignificant effects on rehydration times of powders. Our results support those of Simons et al. (2002) and Mercadé-Prieto et al. (2007) who reported that calcium salts act similarly to sodium in screening charges, but because $\mathrm{Ca}^{2+}$ binds especially to the carboxylates, much lower concentrations are re- 
quired than for $\mathrm{Na}^{+}$to yield the same screening effect. Moreover, monovalent cations do not play a significant role in NWI rehydration at the concentration studied.

The second rehydration behavior was only observed from 2.25 to $12 \% \mathrm{CaCl}_{2}$. The wetting stage was briefly elongated, the swelling stage was still absent, and the total rehydration was significantly prolonged. Ju and Kilara (1998) also observed that a variation in $\mathrm{CaCl}_{2}$ concentration (from 5 to $50 \mathrm{mM}$ ) greatly affected the denaturation behavior of WPI solutions, resulting in a turbidity increase. The turbidity increase at the end of the profile may be due to protein unfolding/denaturation rather than powder rehydration. According to earlier studies (Kuhn and Foegeding, 1991; Caussin et al., 2003), divalent cations may affect electrostatic interactions between charged protein molecules more significantly than monovalent cations. In this study, divalent cations also had a more significant effect on whey protein systems than monovalent cations. The turbidity increase at the end of the rehydration profile may be attributed to intermolecular association of $\mathrm{Ca}^{2+}$ with whey protein. As a result, small aggregates may be formed and detected by the turbidity sensor. The $\mathrm{CaCl}_{2}$ was more effective at screening electrostatic interactions than $\mathrm{NaCl}$ due to higher valency of counterions and because calcium ion can form ion bridges between negatively charged protein molecules. This whole phenomenon may influence the rehydration behavior of NWI powder. These findings are in agreement with those of Kuhn and Foegeding (1991) and Bryant and McClements (2000).

From the FTIR spectra, it could be noticed that spectra corresponding to whey proteins differed in intensity with the addition of salt. It would be of interest to evaluate quantitatively changes in structures ( $\alpha$-helix, turns, irregular, and $\beta$-sheet) by curve fitting and tentative assignments as already accomplished by Curley et al. (1998) on micellar casein. This work will be done in a future study. Similar results were obtained for $\beta$-lactoglobulin rehydrated first at pH 2 and 7 and then heated at $85^{\circ} \mathrm{C}$ (Schmitt et al., 2009). It was concluded that the main consequence at these $\mathrm{pH}$ levels was protein denaturation and not aggregation. One hypothesis is that in a highly ionic environment, NWI may be more prone to denaturation and less to aggregation. For instance, Schmitt et al. (2009) demonstrated that the relative sensitivity of band attributed to $\beta$-sheet and unordered/ $\alpha$-helix secondary structure was a clear indicator of differences in the denaturation/aggregation balance. This point will need to be studied in detail in further studies.

\section{CONCLUSIONS}

The interpretation of the turbidity profiles was helpful to better understand the rehydration stages of native micellar casein and native whey protein isolate powders in increasingly salty environments. We observed 2 distinct behaviors depending on the salt type and concentration: $\mathrm{CaCl}_{2}$ seemed to act in a manner similar to $\mathrm{NaCl}$, but a lower concentration was required to destructure (casein) or unfold (whey) the proteins. Nevertheless, multiscale characterization will be required to investigate more precisely the structure of the 2 proteins in these environments. This will be done in a future paper by coupling transmission electron microscopy, dynamic light scattering, reverse-phase HPLC, and FTIR curve fitting.

\section{ACKNOWLEDGMENTS}

The authors are gratefully indebted to the Pakistan Ministry of Higher Education Commission (HEC) for financial support.

\section{REFERENCES}

Anema, S. G., D. N. Pinder, R. J. Hunter, and Y. Hemar. 2006. Effects of storage temperature on the solubility of milk protein concentrate (MPC85). Food Hydrocoll. 20:386-393.

Bryant, C. M., and D. J. McClements. 2000. Influence of sucrose on $\mathrm{NaCl}$-induced gelation of heat denatured whey protein solutions. Food Res. Int. 33:649-653.

Caussin, F., M. H. Famelart, J. L. Maubois, and S. Bouhallab. 2003. Mineral modulation of thermal aggregation and gelation of whey proteins: From $\beta$-lactoglobulin model system to whey protein isolate. Lait 83:353-364.

Curley, D. M., T. F. Kumosinski, J. J. Unruh, and H. M. Farrell Jr.. 1998. Changes in the secondary structure of bovine casein by fourier transform infrared spectroscopy: Effects of calcium and temperature. J. Dairy Sci. 81:3154-3162.

Famelart, M. H., Y. Le Graët, and K. Raulot. 1999. Casein micelle dispersions into water, $\mathrm{NaCl}$ and $\mathrm{CaCl}_{2}$ : Physicochemical characteristics of micelles and rennet coagulation. Int. Dairy J. 9:293-297.

Farrell, H. M., R. Jimenez-Flores, G. T. Bleck, E. M. Brown, J. E. Butler, L. K. Creamer, C. L. Hicks, C. M. Hollar, K. F. Ng-KwaiHang, and H. E. Swaisgood. 2004. Nomenclature of the proteins of cows' milk - Sixth revision. J. Dairy Sci. 87:1641-1674.

Fauquant, J., J. L. Maubois, and A. Pierre. 1988. Microfiltration du lait sur membrane minérale. Tech. Lait. 1028:21-23.

Freudig, B., S. Hogekamp, and H. Schubert. 1999. Dispersion of powders in liquids in a stirred vessel. Chem. Eng. Process. 38:525532.

Gaiani, C., S. Banon, J. Scher, P. Schuck, and J. Hardy. 2005. Use of a turbidity sensor to characterize micellar casein powder rehydration: Influence of some technological effects. J. Dairy Sci. 88:2700-2706.

Gaiani, C., J. Scher, J. J. Ehrhardt, M. Linder, P. Schuck, S. Desobry, and S. Banon. 2007. Relationships between dairy powder surface composition and wetting properties during storage: importance of residual lipids. J. Agric. Food Chem. 55:6561-6567. 
Gaucheron, F., Y. Le Graët, and V. Briard. 2000. Effect of NaCl addition on the mineral equilibrium of concentrated and acidified casein micelles. Milchwissenschaft 55:82-86.

Grufferty, M. B., and P. F. Fox. 1985. Effect of added NaCl on some physicochemical properties of milk. Int. J. Food Sci. Technol. 9:1-9.

Havea, P. 2006. Protein interactions in milk protein concentrate powders. Int. Dairy J. 16:415-422.

Huppertz, T., and P. F. Fox. 2006. Effect of $\mathrm{NaCl}$ on some physicochemical properties of concentrated bovine milk. Int. Dairy J. 16:1142-1148.

Jayaprakasha, H. M., and H. Brueckner. 1999. Whey protein concentrate: A potential functional ingredient for food industry. J. Food Sci. Technol. 36:189-204.

Jost, R. 1993. Functional characteristics of dairy proteins. Trends Food Sci. Technol. 4:283-288.

Ju, Z. Y., and A. Kilara. 1998. Aggregation induced by calcium chloride and subsequent thermal gelation of whey protein isolate. J. Dairy Sci. 81:925-931.

King, N. 1966. Dispersibilty and reconstitutability of dried milk. Dairy Sci. (Abstr.) 28:105-118.

Kinsella, J. E. 1982. Food proteins relationship between structure and functional properties of food proteins. Pages 51-105 in Food Proteins. P. F. Fox and J. J. Condon, ed. Applied Science Publishers, New York, NY.

Kinsella, J. E. 1984. Milk proteins: Physicochemical and functional properties. Crit. Rev. Food Sci. Nutr. 21:197-262.

Kinsella, J. E., D. M. Whitehead, J. Brady, and N. A. Bringe. 1989. Milk proteins: Possible relationships of structure and function. Pages 53-93 in Development in dairy chemistry. P. F. Fox, ed. Applied Science Publishers, London, UK.

Kuhn, P. R., and E. A. Foegeding. 1991. Mineral salt effects on whey protein gelation. J. Agric. Food Chem. 39:1913-1916.
Maubois, J. L. 2002. Membrane microfiltration: A tool for a new approach in dairy technology. Aus. J. Dairy Technol. 57:92-96.

Mercadé-Prieto, R., R. J. Falconer, W. R. Paterson, and D. I. Wilson. 2007. Swelling and dissolution of $\beta$-lactoglobulin gels in alkali. Biomacromolecules 8:469-476.

Mimouni, A., H. C. Deeth, A. K. Whittaker, M. J. Gidley, and B. R. Bhandari. 2009. Rehydration process of milk protein concentrate powder monitored by static light scattering. Food Hydrocoll. 23:1958-1965.

Philippe, M., Y. Le Graët, and F. Gaucheron. 2005. The effects of different cations on the physicochemical characteristics of casein micelles. Food Chem. 90:673-683.

Pierre, A., J. Fauquant, Y. Le Graët, M. Piot, and J. L. Maubois. 1992. Préparation de phosphocaséinate natif par microfiltration sur membrane. Lait 72:461-474.

Schmitt, C., C. Bovay, A. M. Vuilliomenet, M. Rouvet, L. Bovetto, R. Barbar, and C. Sanchez. 2009. Multiscale characterization of individualized $\beta$-lactoglobulin microgels formed upon heat treatment under narrow pH range conditions. Langmuir 25:7899-7909.

Schuck, P. A. Davenel, F. Mariette, V. Briard, S. Méjean, and M. Piot. 2002. Rehydration of casein powders: Effects of added mineral salts and salt addition methods on water transfer. Int. Dairy J. $12: 51-57$.

Simons, J. W. F. A., H. A. Kosters, R. W. Visschers, and H. H. J. De Jongh. 2002. Role of calcium as trigger in thermal $\beta$-lactoglobulin aggregation. Arch. Biochem. Biophys. 406:143-152.

Swaisgood, H. E. 1996. Characteristics of milk. Pages 841-878 in Food Chemistry. 3rd ed. O. R. Fennema, ed. Marcel Dekker, New York, NY.

Walstra, P., T. J. Geurts, A. Noomen, A. Jellema, and M. A. J. S. van Boekel. 1999. Milk powder. Pages 445-470 in Principles of Milk Properties and Processes. Marcel Dekker, New York, NY. 